\title{
Kinetics and Isotherm Studies of Copper Removal by Brushite Calcium Phosphate: Linear and Non-Linear Regression Comparison
}

\author{
ADNANE EL HAMIDI*, SAID ARSALANE AND MOHAMED HALIM \\ Laboratoire des Matériaux Composites, Polymères et Environnement \\ Faculté des Sciences, B.P. 1014, Rabat, Morocco \\ adnane_el@hotmail.com
}

Received 14 November 2011; Accepted 16 January 2012

\begin{abstract}
Interactions of $\mathrm{Cu}(\mathrm{II})$ ions with calcium phosphate Brushite (DCPD) in aqueous solutions were investigated by batch conditions and under several sorption parameters like contact time, $\mathrm{pH}$ of solution and initial metal concentration. The retention of copper was found maximum and dominated by exchange reaction process in the $\mathrm{pH}$ range 4-6. The reaction process was found initially fast and more than $98 \%$ was removed at equilibrium. The kinetics data of batch interaction was analyzed with various kinetic models. It was found that the pseudo-first order model using the non-linear regression method predicted best the experimental data. Furthermore, the adsorption process was modeled by Langmuir isotherm and the removal capacity was $331.64 \mathrm{mg} \cdot \mathrm{g}^{-1}$. Consequently, $\mathrm{Cu}^{2+}$ concentration independent kinetics and single surface layer sorption isotherm are then suggested as appropriate mechanisms for the whole process.
\end{abstract}

Keywords: Brushite, Calcium phosphate, Copper, Sorption, Isotherm.

\section{Introduction}

Water contamination by metallic pollutants is one of the major environmental concerns for many years because their non-biodegradabilility and their bioaccumulation in organisms may produce undesirable effects on health and ecological environment. The presence of toxic heavy metals in water is mainly rising from mining, metallurgy, abandoned disposal sites and fertilizer industries. Like other metallic ions, copper is included in this class of pollutants even in low concentrations. Its excessive indigestion may cause serious toxicological problems, such as vomiting, cramps, convulsions or even death ${ }^{1}$. Various treatment technologies for the removal of heavy metal ions from wastewater have been used, including chemical precipitation, filtration, coagulation-floculation and electroflotation ${ }^{2}$. However, in the last decades the adsorption/desorption as much as the ionexchange processes have received much attention. Activated carbon is the most widely known adsorbent because of its extensive porosity and large surface area. However, due to 
its high cost, many researchers have focused on cheaper alternates and available adsorbents, such as agricultural by-products, biomass, chitosan, natural zeolite, clay and others ${ }^{3}$. Cation exchangers with sulfonic acid groups $\left(\mathrm{SO}_{3} \mathrm{H}^{-}\right)$or with carboxylic acid groups $(-\mathrm{COOH})$ with hydrogen atom being the exchangeable ion, zeolites and doped zeolites exhibit also relatively better ion exchange capacity ${ }^{4}$. The immobilization of copper ions on phosphate minerals and anhydrous calcium phosphate compounds has been extensively investigated by several authors. Some of them reported the dissolution-precipitation mechanism as the one responsible for removing the metal ions by $\beta-\mathrm{Ca}_{3}\left(\mathrm{PO}_{4}\right)_{2}, \mathrm{Ca}\left(\mathrm{H}_{2} \mathrm{PO}_{4}\right)_{2}, \mathrm{H}_{2} \mathrm{O}$ and $\beta-\mathrm{Ca}_{3}\left(\mathrm{PO}_{4}\right)_{2}$, $\mathrm{xH}_{2} \mathrm{O}^{5,6}$, while others reported the interaction between $\mathrm{Cu}^{2+}$ and hydroxyapatite or monetite $\mathrm{CaHPO}_{4}$ modified by amino silanes as being a complex mechanism including ion exchange, surface dissolution, surface adsorption and precipitation ${ }^{7,8}$. In our recent work, the interaction of copper ions with the calcium phosphate Brushite (DCPD, $\mathrm{CaHPO}_{4}, 2 \mathrm{H}_{2} \mathrm{O}$ ) has been studied ${ }^{9}$. Compared with apatitic phosphates, the Brushite support material possesses better performance to adsorb and retain copper metal ions from aqueous solutions because it's lamellar structure gives more free interspaces. In high copper concentrations, new calcium phosphate solid solution $\mathrm{Ca}_{1-\mathrm{x}} \mathrm{Cu}_{\mathrm{x}} \mathrm{HPO}_{4}, 2 \mathrm{H}_{2} \mathrm{O}$ has been identified and characterized. Isolated materials have revealed high thermal stability with respect to the pure DCPD.

The present study is an extension of our research on the possible use of Brushite phosphate as available adsorbent matrix for divalent metals, which can then be useful as a catalytic formulation in liquid phase catalysis. The main objective was to investigate the kinetic and equilibrium models of $\mathrm{Cu}$ (II) removal by calcium phosphate Brushite (DCPD, $\mathrm{CaHPO}_{4}$, $2 \mathrm{H}_{2} \mathrm{O}$ ). Two regression techniques have been used and compared in order to evaluate correctly the different parameters of the sorption process.

\section{Materials and Methods}

\section{Chemicals}

The Brushite sample $\mathrm{CaHPO}_{4}, 2 \mathrm{H}_{2} \mathrm{O}$ (DCPD) used in this study, as sorbent, was supplied by Riedel-de Haën, after being analyzed and characterized. The source of divalent copper ions were purchased from Merck as nitrate salt $\mathrm{Cu}\left(\mathrm{NO}_{3}\right)_{2}, 3 \mathrm{H}_{2} \mathrm{O}$, because of the low chelating capacity of $\mathrm{NO}_{3}{ }^{-}$with respect to the metal ions. Stock copper solutions $(0.1 \mathrm{M})$ were initially prepared in deionised double distilled water and preserved in tight bottle at $10^{\circ} \mathrm{C}$. Working solutions with concentrations from 40 to $200 \mathrm{mg} / \mathrm{l}$ of metal ions were prepared by appropriate dilutions of the stock solutions immediately prior to their use. The $\mathrm{pH}$ was adjusted by adding $0.1 \mathrm{M} \mathrm{HCl}$ or $0.1 \mathrm{M} \mathrm{NaOH}$.

\section{Procedure}

The experiments were carried out by shaking $0.1 \mathrm{~g}$ of DCPD powder with $100 \mathrm{ml}$ aqueous solution of $\mathrm{Cu}(\mathrm{II})$ using the batch method at room temperature, viz. $18^{\circ} \mathrm{C}$. After predetermined contact time interval, solids were separated from solutions by filtration through membrane filter $(45 \mu \mathrm{m}) . \mathrm{Cu}(\mathrm{II})$ concentrations in aqueous solutions were measured using GBC $911 \mathrm{UV}-$ Visible spectrophotometer after preliminary calibration with standard solutions of divalent copper. The value of the $\mathrm{pH}$ was measured by a pH-meter Hanna pH-211R equipped with an electrode of glass combined HI1131B.F or comparison, the copper retained by solid samples were also analyzed by inductively coupled plasma atomic emission spectroscopy ICP-AES (Jobin Yvon, Ultima 2) after dissolution in nitric acid.

All batch experiments were conducted in duplicate and the values were reported average of two readings. 


\section{Adsorption Kinetics}

The Kinetic study determines how a reaction between metal ions in solution and adsorbent matrix advances by following an appropriate pathway. Several models have been proposed in order to estimate the removal rate that takes place, the kinetic parameters and the concerned mechanism of the process ${ }^{10}$.

The pseudo-first order model, based on solid capacity, expresses the mechanism of removal as a sorption preceded by diffusion through a boundary ${ }^{11}$. It considers that the adsorption is partial first ordered depending on the concentration of free sites. The pseudo-first order equation is generally expressed as follows ${ }^{12}$ :

$$
\frac{d q}{d t}=k_{1}\left(q_{e}-q_{t}\right)
$$

where $\mathrm{q}_{\mathrm{t}}(\mathrm{mg} / \mathrm{g})$ is the amount of $\mathrm{Cu}(\mathrm{II})$ removed at time $\mathrm{t}$. It is expressed as:

$$
\mathrm{q}_{\mathrm{t}}=\left(\mathrm{C}_{0}-\mathrm{C}_{\mathrm{t}}\right) . \mathrm{Vm}
$$

$\mathrm{q}_{\mathrm{e}}$ is the amount of metal adsorbed at equilibrium $(\mathrm{mg} / \mathrm{g}), \mathrm{k}_{1}$ is first-order rate constant (1/min).

On the other hand, the pseudo-second order model is based on chemical sorption ${ }^{13}$. It expresses the adsorption as being partial second ordered with respect to free sites. Mathematically, it can be represented in the following form:

$$
\frac{d q}{d t}=k_{2}\left(q_{e}-q_{t}\right)^{2}
$$

where $\mathrm{k}_{2}$ (g/mg.min) is the pseudo-second order removal rate constant.

In order to determine if the concentration of the solute in solution is rate limiting step in the kinetic, the Adam-Bohart-Thomas relation ${ }^{14}$ was used. It describes the adsorption as being partial first ordered in accordance to free sites and partial first ordered with respect to concentration of solute in solution. The general expression is as follows:

$$
\frac{d q_{t}}{d t}=k_{a d s} C_{t}\left(q_{e}-q_{t}\right)
$$

The derived linear and non-linear equations of each model were summarized in table 1.

To estimate the validity of each kinetic model, the sum of errors squared (SSE) was calculated. The best fit to sorption show the lowest values of $\mathrm{SSE}^{15}$.

$$
\mathrm{SSE}=\sqrt{\frac{\sum_{t=0}^{n}\left[q_{t, \exp }-q_{t, c a l}\right]^{2}}{N}}
$$

where the subscripts (exp) and (cal) are the experimental and the calculated values of $\mathrm{q}$ respectively and $\mathrm{N}$ is the number of measurements.

\section{Adsorption Isotherms}

The phenomenon governing the transfer of metals from aqueous phase to the adsorbent is described by the adsorption isotherms. The curve $q_{e}=f\left(C_{e}\right)$, which is the plot of the quantity of sorbate removed per unit of sorbent $\left(\mathrm{q}_{\mathrm{e}}\right)$ against the concentration of sorbate in the liquid phase $\left(\mathrm{C}_{\mathrm{e}}\right)$, is the most used one for this description. Concerning the 
isotherm models that were developed, Langmuir and Freundlich have been used in this study.

The Langmuir isotherm deals with the unimolecular thick layer of adosrbate upon the surface of an homogeneous adsorbent without having any interactions between adsorbed molecules. Its mathematical form is given $b y^{16}$ :

$$
q_{e}=\frac{q_{\max } \cdot K_{L} C_{e}}{1+K_{L} C_{e}}
$$

Whose linear form is:

$$
\frac{1}{q_{e}}=\frac{1}{K_{L} \cdot q_{\max }} \cdot \frac{1}{C_{e}}+\frac{1}{q_{\max }}
$$

where $C_{e}$ is the equilibrium concentration $\left(m g .1^{-1}\right.$ ), $q_{e}$ and $q_{\max }$ are respectively the amount and maximum amount of metal ion sorbed at equilibrium per unit weight of sorbent $\left(\mathrm{mg} . \mathrm{l}^{-1}\right)$ and $\mathrm{K}_{\mathrm{L}}$ is the equilibrium adsorption constant.

On the other hand, the Freundlich isotherm encompasses the heterogeneity of the surface and the exponential distribution of sites and their energies. The equation of the Freundlich adsorption isotherm is as the following form ${ }^{17}$ :

And the linear form is:

$$
q_{e}=K_{F} C^{\frac{1}{n}}
$$

$$
\log q_{e}=\log K_{F}+\frac{1}{n} \log C_{e}
$$

where $\mathrm{K}_{\mathrm{F}}$ and $\mathrm{n}$ represent the Freundlich constants describing the characteristics of the system. They are related to the adsorption capacity and adsorption intensity respectively.

\section{Results and Discussion}

\section{Effect of Initial $p H$}

The $\mathrm{pH}$ is a very important parameter that affects significantly the sorption of metals, since the degree of ionization of the metal ions and the solubility of the sorbent depends upon it ${ }^{18}$. The solubility of DCPD has been estimated by analyzing the changes in phosphorus concentration of the solution. After contacting $1 \mathrm{~g}$ of solid in distilled water of different $\mathrm{pHs}$ for 120 minutes at $200 \mathrm{rpm}$, we have confirmed the high solubility of Brushite below pH 3 (figure 1) which is in good agreement with the results obtained by Shashkova et al. ${ }^{18}$.

Thus, taking into account the precipitation $\mathrm{pH}$ of $\mathrm{Cu}(\mathrm{II})^{19}$, and the dissolution of DCPD at $\mathrm{pH} 3$ being a critical point, the effect of initial $\mathrm{pH}$ on interaction of $\mathrm{Cu}^{2+}$ with DCPD was studied over a range of 3 to 7 .

The results in Figure 1 show also the percent uptake of copper from solution of concentration $(100 \mathrm{mg} / \mathrm{l})$ at room temperature. The small amount adsorbed at $\mathrm{pH} 3$, could be due to the competition between protons and metal ions for active sites ${ }^{20,21}$. From $\mathrm{pH} 4$, the removal becomes important attaining 98\%. Subsequently, the kinetic and isotherm experiments were carried out at $\mathrm{pH}$ ranging between 4 and 6 and the results thus obtained were in good agreement with the previous findings ${ }^{22-24}$. 
Table 1. Non-linear and linear equations of different kinetic models.

\begin{tabular}{|c|c|}
\hline Kinetic models & Non-linear equations \\
\hline Pseudo-first order model & $\log \left(q_{e}-q_{t}\right)=\log \left(q_{e}\right)-\frac{k_{1}}{2.303} t$ \\
\hline $\begin{array}{l}\text { Pseudo-second order } \\
\text { model }\end{array}$ & $\frac{t}{q_{t}}=\frac{1}{k \cdot q_{e}^{2}}+\left(\frac{1}{q_{e}}\right) t$ \\
\hline $\begin{array}{l}\text { Adam-Bohart-Thomas } \\
\text { model }\end{array}$ & $\left.q_{t}=\frac{C_{0}}{m_{s}} \cdot \frac{1-\exp \left[k_{a d s} m_{s}\left(\frac{C_{0}}{m_{s}}-q_{m}\right) \cdot t\right]}{1-\frac{1}{q_{m}} \frac{C_{0}}{m_{s}} \exp \left[k_{a d s} m_{s}\left(\frac{C_{0}}{m_{s}}-q_{m}\right) t\right]} \ln \frac{C_{0} / m_{s}-q_{t}}{q_{m}-q_{i}}=\ln \left(\frac{C_{0}}{q_{m} m}\right)+\left[\left(\frac{C_{0}}{m_{s}}\right)-q_{m}\right) k_{a d s} m_{s}\right] t$ \\
\hline
\end{tabular}

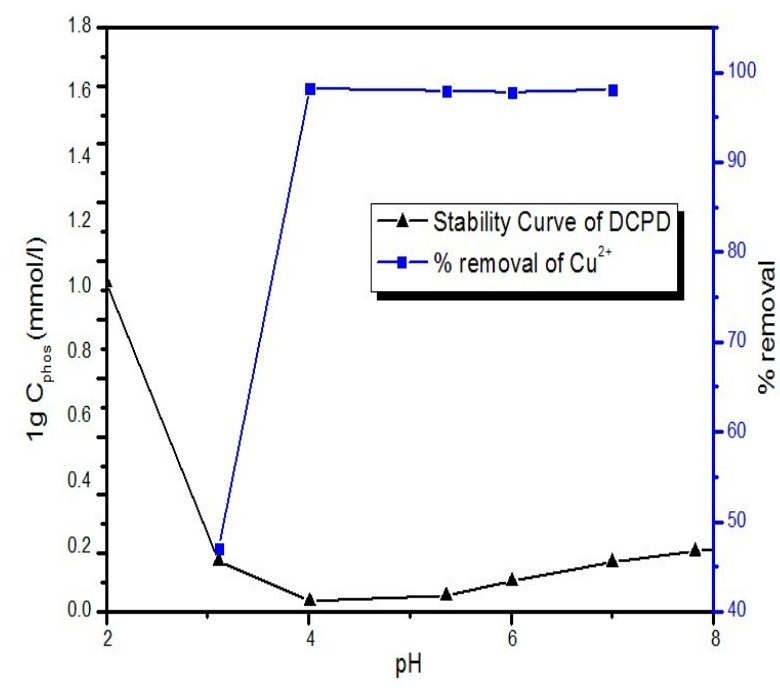

Figure 1. Influence of $\mathrm{pH}$ upon the removal of $\mathrm{Cu}(\mathrm{II})$ on Brushite (DCPD) $\mathrm{C}_{\text {initial }}=100 \mathrm{mg} / \mathrm{L} ; \mathrm{V}=100 \mathrm{~mL}$.

\section{Kinetic experiments}

\section{Effect of Contact Time}

To study the effect of shaking time, a series of suspensions with $0.1 \mathrm{~g}$ of DCPD and initial metal concentrations of 50,100 and $200 \mathrm{mg} / 1$ were shaken for different time intervals ranging from 5 to 400 minutes at room temperature. Figure 2 displays a three dimensional representation of evolution of the amount of copper removed, the variation of $\mathrm{pH}$ and time. A 3D surface has been generated by converting the worksheet data to matrix by the gridding process with the help of the Originlab 8.5 software. 


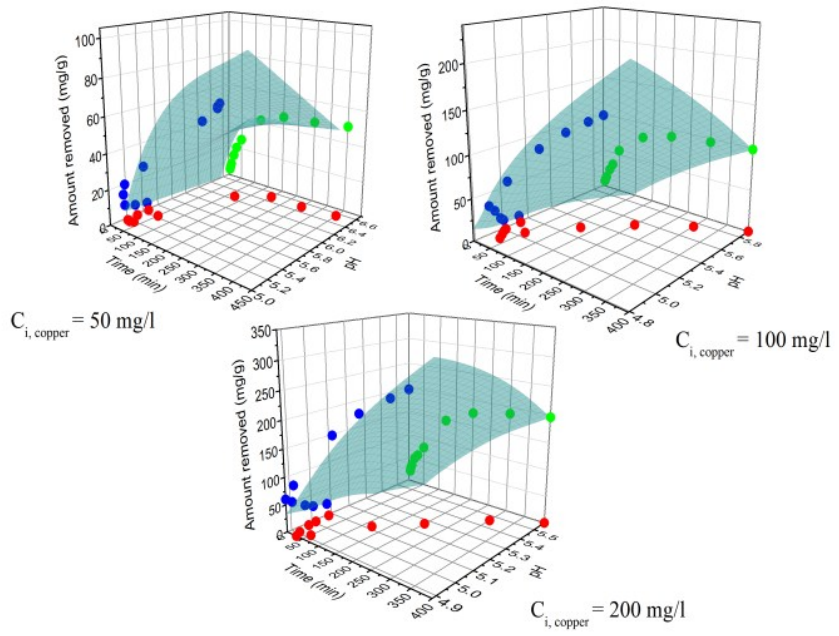

Figure 2. 3D surface representation of the effect of contact time on the amount of copper removed by Brushite (DCPD) and on the $\mathrm{pH}$ of solution.

It can be seen that the sorption increased with increasing contact time and the equilibrium was attained after 400 minutes of shaking, during which an amount of 50,99 and $196 \mathrm{mg} / \mathrm{g}$ was removed for 50,100 and $200 \mathrm{mg} / \mathrm{l}$ of initial metal concentrations respectively. A sharp increase in uptake was observed during the first two hours with more than $70 \%$ of metal ion is taken up, but it slows down gradually from 120 to 400 minutes of shaking before attaining equilibrium. It's expected that the process of sorption is through ion exchange followed by chemisorption $^{25}$. In fact, the Brushite skeleton has formed by pseudo-layers structure which accommodates the $\mathrm{Ca}^{2+}$ and $\mathrm{H}^{+}$cations. These cations may be replaced by copper in solutions. The first high removal occurred because of the availability of a large number of adsorbent sites and rapid diffusion of metal ions form solution to active surface sites. With the passage of time, the amount of active sites gradually decreases which causes retardation in sorption process.

Values of $\mathrm{pH}$ have been measured during each interval of time. It decreased during the first half an hour of shaking by half unity before it increases gradually until equilibrium is reached. The first decrease corresponds to the initial amount of copper readily adsorbed. The next gradual increase, which is less pronounced as the concentration of $\mathrm{Cu}^{2+}$ is high, was may be due to the limited buffer effect of DCPD. Otherwise, the $\mathrm{pH}$ reaches 7.7 when the same amount of DCPD is put alone in water. A similar effect of limited protonation have been observed in the interaction of $\mathrm{Cu}^{2+}, \mathrm{Zn}^{2+}$ and $\mathrm{Pb}^{2+}$ with the apatitic calcium phosphate structure $^{26}$.

\section{Kinetic Studies}

The experimental data sets were fitted to the linear form of each model and table 1 resumes the different equations used. The Slopes and intercepts of plots of the linear representations (figure 3) were obtained to determine the rate constants $\mathrm{k}$ and equilibrium adsorption amount $\mathrm{q}_{\mathrm{e}}$ of the pseudo-first order, pseudo-second order and Adam-BohartThomas expressions. The calculated kinetic constants were summarized in table 2. It was observed that the correlation factor values were high for the pseudo-first and pseudo-second order models $(0,99)$ but were low for the Adam-Bohart-Thomas model. The SSE values 
confirms the good fit of the experimental data with the pseudo-second order model more than with the pseudo-first order one and the inadequate fit with the Adam-Bohart-Thomas one. In consequence, by the linear regression method the pseudo-second order model was found to well define the kinetic of adsorption of $\mathrm{Cu}^{2+}$ into the DCPD compound.

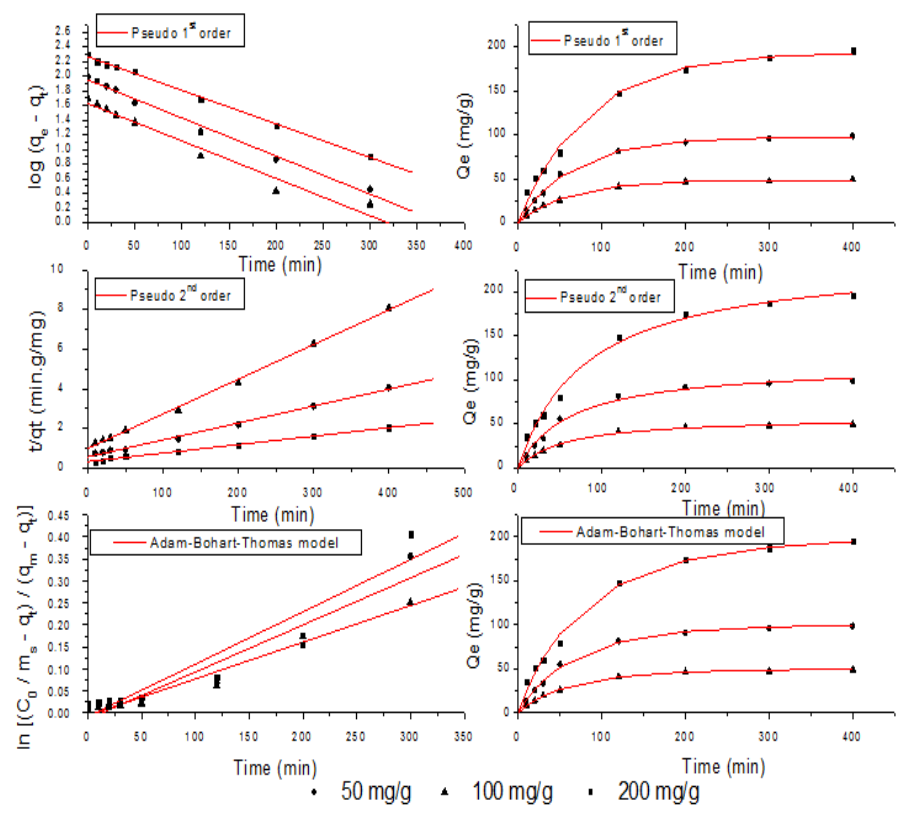

Figure 3. Sorption kinetic of copper on Brushite (DCPD) Right: Non-linear regression analysis Left: Linear regression analysis.

The Non-linear regression has been performed by using the curve fitting technique with Microsoft Excel. Figure 3 shows the different fitting curves. From table 2, all the models have high values of $\mathrm{R}^{2}$. Since it is known that the model giving lower values of SSE is a better one in describing the kinetic of a system ${ }^{15}$, the Adam-Bohart-Thomas relation seems to fit best the experimental results. But when considering its determined theoretical constants, it is observed that the $\mathrm{q}_{\mathrm{e}}$ values are very high, inducing the rejection of this model. However, the pseudo-first order predicts better the theoretical $\mathrm{q}_{\mathrm{e}}$ values than the pseudosecond order. With respect to the $\mathrm{R}^{2}$ and SSE values, the pseudo-first order seems to describe well the experimental data.

Comparing the results obtained from the linear and non-linear regression, it appears that there is a great difference between the constants determined in both pseudo-first order and Adam-Bohart-Thomas expressions. Contrarily, the linear and non linear form of the pseudosecond order relation gives almost similar results. As it has been reported previously ${ }^{27,28}$, the transformation of the non-linear equation to the linear form shows significant problems in estimating kinetic parameters. It alters the error structure and may also violate the error variance and normality of standard least-square $\mathrm{s}^{29,30}$. Therefore, the linear equation of the pseudo-first order model and Adam-Bohart-Thomas is not appropriate to use comparative to the non-linear regression technique which is more suitable. In case of the pseudo-second 
order model, despite the good adequacy between kinetic parameters obtained by the linear and non-linear regression technique, the non-linear method still gets preference.

Table 2. Kinetic data obtained by linear and non-linear regression of three kinetic models.

\begin{tabular}{|c|c|c|c|c|c|c|c|c|c|}
\hline \multicolumn{10}{|c|}{ Lagergren's Pseudo-first order model } \\
\hline \multirow{2}{*}{$\begin{array}{c}\mathrm{C}_{\mathrm{i}} \\
(\mathrm{mg} / \mathrm{l})\end{array}$} & \multirow{2}{*}{$\begin{array}{c}\begin{array}{c}\mathrm{Q}_{\mathrm{e}} \\
(\exp )\end{array} \\
(\mathrm{mg} / \mathrm{g})\end{array}$} & \multicolumn{4}{|c|}{ Linear regression } & \multicolumn{4}{|c|}{ Non-linear regression } \\
\hline & & $\mathrm{R}^{2}$ & $\mathrm{~K}_{1}\left(\min ^{-1}\right)$ & $\begin{array}{c}\mathrm{q}_{\mathrm{e}} \\
(\mathrm{mg} / \mathrm{g})\end{array}$ & SSE & $\mathrm{R}^{2}$ & $\mathrm{~K}_{1}\left(\min ^{-1}\right)$ & $\begin{array}{c}\mathrm{q}_{\mathrm{e}} \\
(\mathrm{mg} / \mathrm{g})\end{array}$ & SSE \\
\hline 50 & 49.49 & 0,983 & 0,0125 & 42,440 & 7,040 & 0.998 & 0.0163 & 48.64 & 0.743 \\
\hline 100 & 98.77 & 0,995 & 0,0120 & 89,090 & 10,123 & 0.998 & 0.0154 & 97.36 & 1.589 \\
\hline 200 & 195.88 & & 0,0105 & 184,200 & 13,320 & 0.991 & & & 6,659 \\
\hline \multicolumn{10}{|c|}{ Pseudo-second order model } \\
\hline \multirow[b]{2}{*}{$\begin{array}{c}\mathrm{C}_{\mathrm{i}} \\
(\mathrm{mg} / \mathrm{l})\end{array}$} & \multicolumn{2}{|l|}{$\mathrm{Q}_{\mathrm{e}}(\exp )$} & \multicolumn{2}{|c|}{ Linear regression } & & \multicolumn{4}{|c|}{ Non-linear regression } \\
\hline & $(\mathrm{mg} / \mathrm{g})$ & $\mathrm{R}^{2}$ & $\begin{array}{c}\mathrm{K}_{2} \\
(\mathrm{~g} / \mathrm{mg} / \mathrm{min})\end{array}$ & $\begin{array}{c}\mathrm{q}_{\mathrm{e}} \\
(\mathrm{mg} / \mathrm{g})\end{array}$ & SSE & $\mathrm{R}^{2}$ & $\begin{array}{c}\mathrm{K}_{2} \\
(\mathrm{~g} / \mathrm{mg} / \mathrm{min})\end{array}$ & $\begin{array}{c}\mathrm{q}_{\mathrm{e}} \\
(\mathrm{mg} / \mathrm{g})\end{array}$ & SSE \\
\hline 50 & 49.49 & 0,999 & $3,12.10^{-4}$ & 57,14 & 1,272 & 0.996 & $2.994 \times 10^{-4}$ & 58.08 & 1.215 \\
\hline 100 & 98.77 & 0,998 & $1,30.10^{-4}$ & 117,10 & 3,251 & 0.994 & $1.338 \times 10^{-4}$ & 117.78 & 3.048 \\
\hline 200 & 195.88 & 0,996 & $5,69,10^{-5}$ & 234,19 & 6,477 & 0.993 & $5.031 \times 10^{-5}$ & 240.44 & 6.161 \\
\hline \multicolumn{10}{|c|}{ Adam-Bohart-Thomas's model } \\
\hline \multirow{2}{*}{$\begin{array}{c}\mathrm{C}_{\mathrm{i}} \\
(\mathrm{mg} / \mathrm{l})\end{array}$} & $\mathrm{Q}_{\mathrm{e}}(\exp )$ & \multicolumn{4}{|c|}{ Linear regression } & \multicolumn{4}{|c|}{ Non-linear regression } \\
\hline & $(\mathrm{mg} / \mathrm{g})$ & $\mathrm{R}^{2}$ & K & $\begin{array}{c}\mathrm{q}_{\mathrm{e}} \\
(\mathrm{mg} / \mathrm{g})\end{array}$ & SSE & $\mathrm{R}^{2}$ & $\mathrm{~K}$ & $\begin{array}{c}\mathrm{q}_{\mathrm{e}} \\
(\mathrm{mg} / \mathrm{g})\end{array}$ & SSE \\
\hline 50 & 49.49 & 0,984 & $2,80.10^{-3}$ & 49,70 & 14,613 & 0.999 & $1,33 \times 10^{-4}$ & 132,84 & 0,020 \\
\hline 100 & 98.77 & 0,960 & $7,75.10^{-4}$ & 98,62 & 22,244 & 0.998 & $4,53 \times 10^{-5}$ & 353,33 & 0,043 \\
\hline 200 & 195.88 & 0,957 & $7,50.10^{-4}$ & 198,41 & 69,295 & 0.994 & $2,80 \times 10^{-5}$ & 478,28 & 0,127 \\
\hline
\end{tabular}

\section{Isotherm Experiments}

\section{Effect of Initial Concentration}

The metal ion adsorption capacity of DCPD was studied over various concentrations of $\mathrm{Cu}^{2+}$. The initial concentrations were ranged from 45-201 mg. $1^{-1}$. The results are shown in figure 4. It clarifies that the amount adsorbed increased with the increase of initial concentration. The amount removed from aqueous solution increased from $44.48 \mathrm{mg}$ to $197.07 \mathrm{mg}$ of $\mathrm{Cu}(\mathrm{II})$ per gram of DCPD.

\section{Isotherm studies}

The adsorption parameters obtained by the linear regression technique are calculated from the slop and intercept of the plots of $1 / \mathrm{q}_{\mathrm{e}}=\mathrm{f}\left(\mathrm{C}_{\mathrm{e}}\right)$ and $\log \left(\mathrm{q}_{\mathrm{e}}\right)=\mathrm{f}\left(\log \left(\mathrm{C}_{\mathrm{e}}\right)\right)$ for the Langmuir and Freundlich isotherms respectively (table 3). 


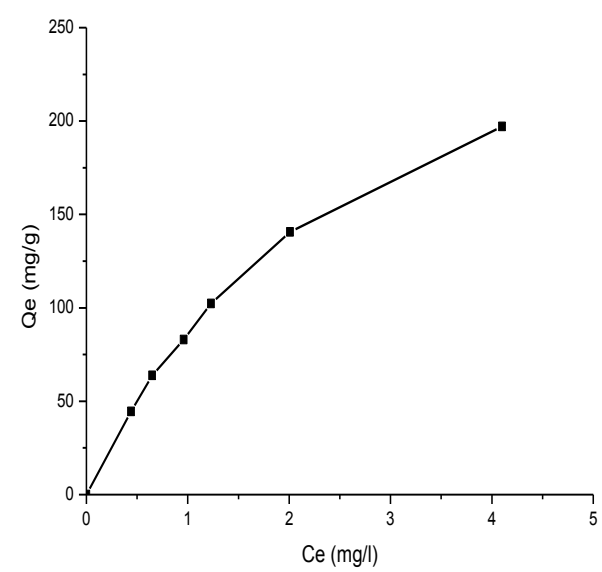

Figure 4. Amount of copper removed by Brushite (DCPD) vs. equilibrium concentration of $\mathrm{Cu}(\mathrm{II})$.

Table 3. Parameters of Langmuir and Freundlich isotherm for sorption of $\mathrm{Cu}(\mathrm{II})$.

\begin{tabular}{lllllll}
\hline & \multicolumn{3}{c}{ Langmuir isotherm } & \multicolumn{3}{l}{ Freundlich isotherm } \\
\hline & $\mathrm{R}^{2}$ & $\mathrm{~K}_{\mathrm{L}}(\mathrm{l} / \mathrm{mg})$ & $(\mathrm{mg} / \mathrm{g})$ & $\mathrm{R}^{2}$ & $\mathrm{~K}_{\mathrm{F}}(\mathrm{mg} .1 / \mathrm{g})$ & $1 / \mathrm{n}$ \\
\hline Linear regression & 0.999 & 0.3404 & 343,64 & 0.993 & 83,43 & 0.666 \\
\hline Non-linear regression & 0.999 & 0.3596 & 331,64 & 0.987 & 86,21 & 0.603 \\
\hline
\end{tabular}

Comparing the results obtained from the two regression techniques (linear and non-linear), we have noticed the difference between them as it has been seen in kinetic study. Subsequently, the use of the non-linear regression is the best way to determine the isotherm parameters.

Thus, considering the results obtained from non-linear regression (table 3), the best correlation coefficient was observed for the Langmuir isotherm (0.999). The maximum monolayer sorption capacity, $\mathrm{q}_{\max }$, and the equilibrium constant, $\mathrm{K}_{\mathrm{L}}$, were found to be $331.64 \mathrm{mg} / \mathrm{g}$ and $0.36 \mathrm{l} / \mathrm{mg}$ respectively.

The dimensionless constant separation factor, $\mathrm{R}_{\mathrm{L}}$, have also been calculated from:

$$
R_{L}=\frac{1}{1+K_{L} C_{i}}
$$

The values were found to vary between 0.0614 and 0.0144 for initial $\mathrm{Cu}$ (II) concentrations ranging from 45 to $200 \mathrm{mg} / \mathrm{l}$. It indicated favorable sorption since they were in the range of 0 to 1 . From the Freundlich sorption isotherm we can consider the 
sorption intensity which is equal to 1.658 confirming a favorable sorption of $\mathrm{Cu}(\mathrm{II})$ onto $\mathrm{DCPD}$, since $\mathrm{n}$ is ranging between 1 and 10 .

The non-linear regression of Langmuir and Freundlich isotherms are shown in figure 5. It can be observed clearly that the Langmuir model fit best the equilibrium experimental data.

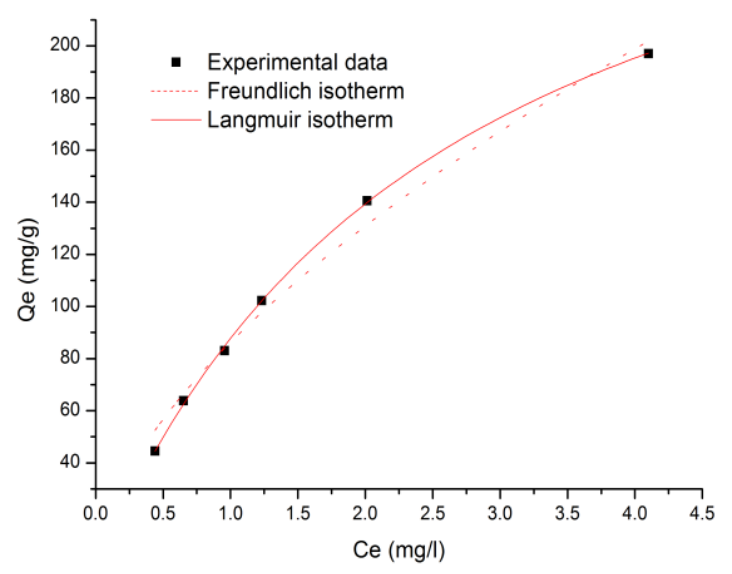

Figure 5. Adsorption isotherms - non-linear regression of copper adsorption on Brushite (DCPD).

\section{Conclusion}

The results of the present study reveal that the Brushite calcium phosphate possesses high performance to remove $\mathrm{Cu}$ (II) from aqueous solutions, in comparison to their homologous apatitic materials and natural phosphate. The retention percentage of copper ions was found greater than $98 \%$ at low acidic $\mathrm{pH}$.

The sorption studies of $\mathrm{Cu}^{2+}$ through the kinetic and equilibrium modeling has been investigated by linear and non-linear regression methods. The analysis of methods showed that the linearization is not appropriate when using the pseudo-first order and Adam-BohartThomas expressions since it affects their error structure. Furthermore, for the pseudo-second order relation as well as for the Langmuir and Freundlich models, the non-linear form is more suitable to be used.

Within the three kinetic models utilized, the pseudo-first order was found to best fit the experimental data, which indicates that the sorbent free sites are the rate-limiting step in the process. The equilibrium isotherm study showed that the experimental data could be well fitted with the Langmuir model inducing the single surface layer adsorption process with no interactions between adsorbed metals.

\section{Acknowledgment}

The authors are grateful for the financial support of this project by research Grant (SCH04/09) of University of Mohamed V, Morocco.

\section{References}

1. Paulino A T, Minasse F A, Guilherme M R, Reis A V, Muniz E C, and Nozaki J, $J$ Colloid Interface Sci., 2006, 301, 479.

2. Fu F and Wang Q, J Environ Manage., 2010, 92, 407.

3. Camilo C, Carmen G and Paula M, J Chem Technol Biot., 2005, 80, 477. 
4. Alexandratos S D, Ind Eng Chem Res., 2008, 48, 338.

5. Shul'ga N V, Shashkova I L, Mil'vit N V, and Rat'ko A I, Russ J Appl Chem., 2007, 80, 1304.

6. Sugiyama S, J Colloid Interface Sci., 2003, 259, 408.

7. Cao X, Ma L Q, Rhue D R, and Appel C S, Environ Pollut., 2004, 131, 435.

8. da Silva O G, da Fonseca M G and Arakaki L N H, Colloid surface A, 2007, 301, 376.

9. El Hamidi A, Halim M, Kacimi M, Arsalane S, and Ziyad M, Asian J Chem., 2012, 24, 2698.

10. Febrianto J, Kosasih A, Sunarso J, Ju Y, Indraswati N, and Ismadji S, J Hazard Mater., 2009, 162, 616.

11. Bhattacharyya K G and Sharma A, J environ manage., 2004, 71, 217.

12. Lagergren S, Handlingar, 1898, 24, 1.

13. Ho Y S, Chiub W T, Hsub C S, and Huang C T, Hydrometallurgy, 2004, 73, 55.

14. Aksu Z and Gonen F, Process Biochem., 2004, 39, 599.

15. Gunay A, Arslankaya E, and Tosun I, J Hazard Mater., 2007, 146, 362.

16. Langmuir I, J Am Chem Soc., 1918, 40, 1361.

17. Freundlich H M F, J Phys Chem., 1906, 56, 385.

18. Shashkova I L, Rat'ko A I, and Kitikova N V, Colloid Surface A, 1999, 160, 207.

19. Zheng W, Li X M, Yang Q, Zeng G M, Shen X X, Zhang Y, and Liu J J, J Hazard Mater., 2007, 147, 534.

20. Pan H B and Darvell B W, Arch Oral Biol., 2009, 54, 671.

21. Pavasant P, Apiratikul R, Sungkhum V, Suthiparinyanont P, Wattanachira S, and Marhaba T, Technol., 2006, 97, 2321.

22. Cao X, Ma L Q, Rhue D R, and Appel C S, Environ Pollut., 2004, 131, 435.

23. Hao Y M, Man C, and Hu Z B, J Hazard Mater., 2010, 184, 392.

24. Amarasinghe B and Williams R, Chem Eng J., 2007, 132, 299.

25. Chutia P, Kato S, Kojima T, and Satokawa S, J Hazard Mater., 2009, 162, 440.

26. El Asri S, Laghzizil A, Coradin T, Saoiabi A, Alaoui A, and M'hamedi R, Colloid Surface A, 2010, 362, 33.

27. Ho Y S, Water Res., 2006, 40, 119.

28. Kumar K V, J Hazard Mater., 2006, 137, 1538.

29. Gimbert F, Morin-Crini N, Renault F, Badot P M, and Crini G, J Hazard Mater., 2008, 157, 34.

30. Ho Y S, Carbon, 2004, 42, 2115. 


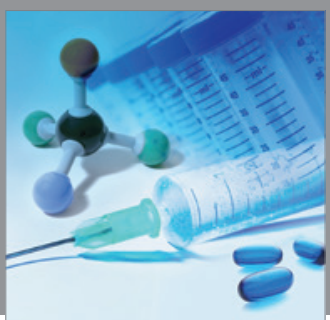

International Journal of

Medicinal Chemistry

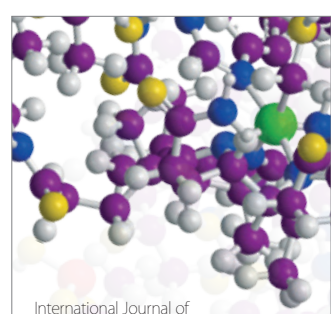

Carbohydrate Chemistry

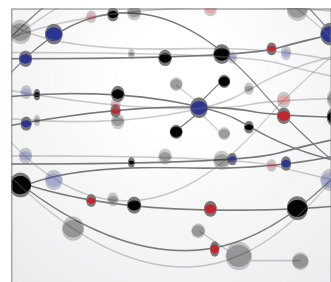

The Scientific World Journal
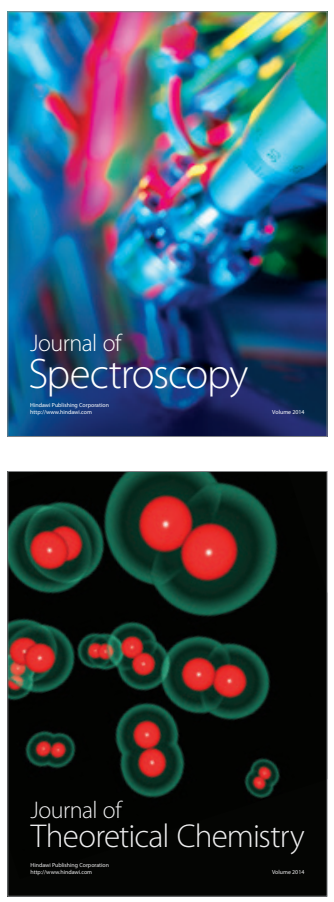
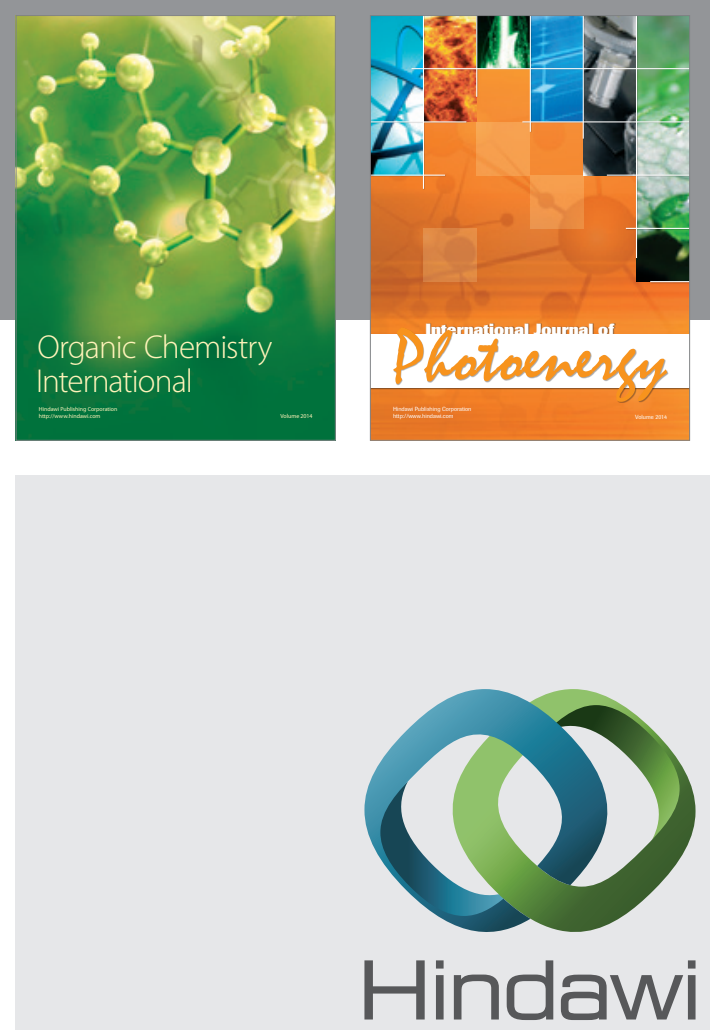

Submit your manuscripts at

http://www.hindawi.com
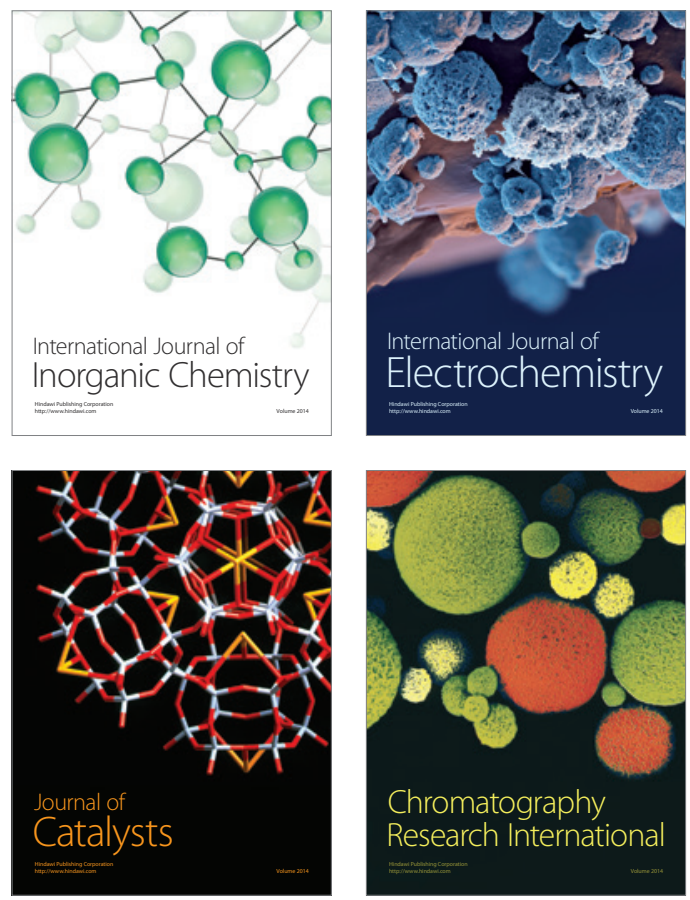
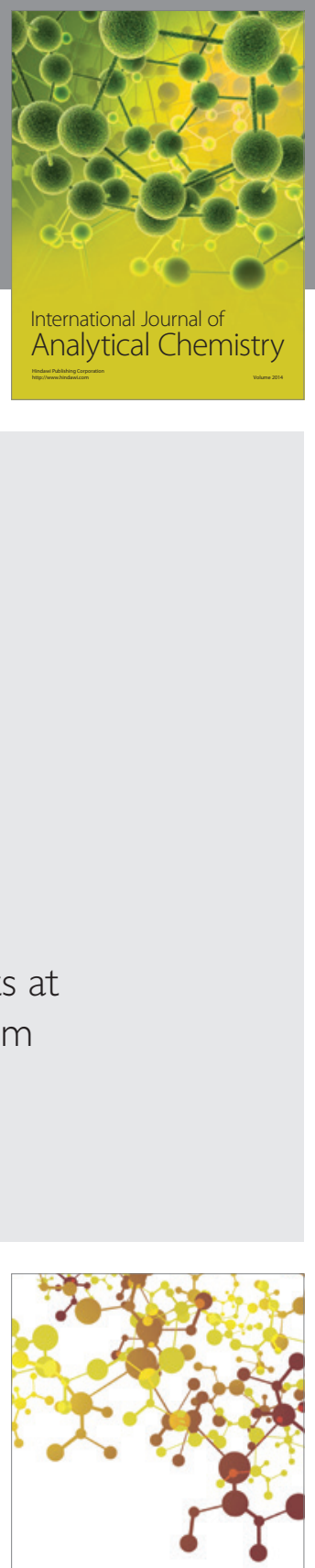

Journal of

Applied Chemistry
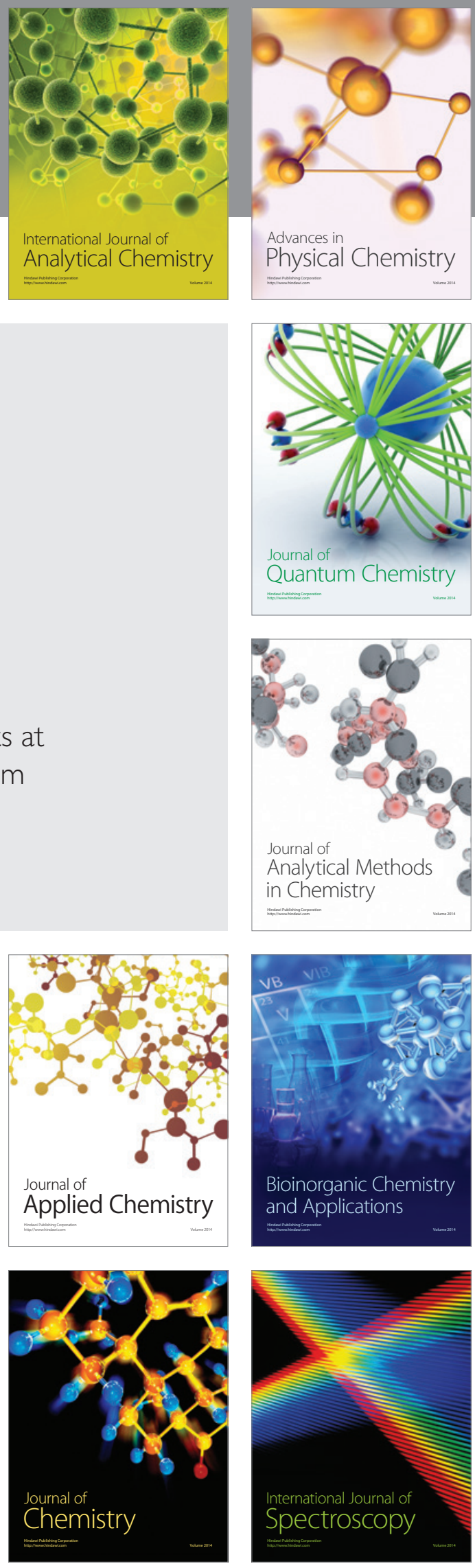